\title{
Growth, mortality and yield of Atherina boyeri Risso, 1810 from Lesina lagoon (Adriatic Sea, Italy)
}

\author{
Ermelinda PRATO ${ }^{*}$, Asia GRATTAGLIANO ${ }^{2}$, Daniela LUMARE ${ }^{3}$, Febo LUMARE $^{3}$ \\ Andrea RUSCITO ${ }^{2}$ and Francesca BIANDOLINO ${ }^{1}$
}

\author{
${ }^{1}$ CNR/IRSA (National Research Council/Water Research Institute), \\ Via Roma 3, 74100 Taranto, Italy \\ ${ }^{2}$ University of Rome “Tor Vergata”, Via della Ricerca Scientifica, 1, 00133 Roma \\ ${ }^{3}$ UNIRIGA (Unità Ricerca Gambericoltura) University of Salento 73100 Lecce, Italy \\ "Corresponding author, e-mail: linda.prato@irsa.cnr.it
}

\begin{abstract}
Population structure, growth, age, mortality and exploitation status of Atherina boyeri, caught in the period from June 2013 to May 2014 in the Lesina lagoon (Apulia region, southern Adriatic) was studied. Samples were taken each month by using beach seines. The length-weight relationship of all sand smell specimens was described by the equation $W=0.012 * T L 3.10 ;(R 2=$ 0.84). Population parameters including the asymptotic length $(L \infty)$ and growth coefficient $(K)$ were assessed to evaluate the stock status. The recruitment pattern was modeled with a FiSAT routine. The asymptotic length $(L \infty)$ was $111.0 \mathrm{~mm}$, while the growth coefficient $(K)$ was 0.68 year-1. The growth performance index ( $(\varphi$ ') reached 3.92. The total mortality coefficient " $Z$ ", the natural mortality coefficient " $M$ " and the fishing mortality coefficient " $F$ " were estimated as $2.24,1.48$ and 0.76 year-1, respectively. Exploitation rate for the population of A. boyeri in the Lesina lagoon estimated as 0.34 was resulted still lower than the predicted maximum value of Emax 0.59. The probability of capture indicated that L50 was of $55.57 \mathrm{~mm}$, indicating that the stock of sand smelt in Lesina lagoon is not being over-fished.
\end{abstract}

Key words: Atherina boyeri, month variations, age, growth, mortality, exploitation, Lesina lagoon, Adriatic Sea

\section{INTRODUCTION}

Coastal lagoons are shallow aquatic environments, typically located between terrestrial and marine ecosystems. They are characterized by a marked variability with wide and rapid changes in environmental parameters, such as salinity, dissolved oxygen, temperature, turbidity, availability of food and the structural characteristics of the habitat (GORDO \& CABRAL, 2001; FRANCO et al., 2006; BASSET et al., 2006). These heterogeneities determine strong environmental variations and, consequently, can cause a selective pressure upon individuals, population and species (MC LUSKY \& ELLIOTT, 2004).

The sand smelt Atherina boyeri Risso, 1810 is typical inhabits of these aquatic ecosystems; it is an euryhaline and eurythermic teleost fish 
species that spends its entire life adapting to over a wide range of salinities and temperatures (ELLIOTT \& DEWAILLY, 1995). It is widespread in temperate regions with a broad area ranges, from the western Atlantic coast of Spain to Marocco and Madeira, and is very common in Mediterranean and Black sea. Within such a broad geographical distribution, sand smelt populations are subject to variety of climatic conditions, and often forming different local populations (QUIGNARD \& PRAS, 1986).

Aspects of the life history of $A$. boyeri have been reported in previous studies at various locations in the Mediterranean (GON \& BENTUVIA,1983; PALLAORO et al., 2002; BARTULOVIĆ et al., 2004; KOUTRAKIS et al., 2004; POMBO et al., 2005; PATIMAR et al., 2009; MACI \& BASSETT, 2010). In the coastal lagoons, the A. boyeri plays an important ecological role in structuring food webs, representing a link between different trophic levels (VIZZINI \& MAZZOLA, 2002, 2005; CHRISAFI et al., 2007). It is considered as a generalist and opportunistic carnivore with food preferences for small crustaceans, both planktonic and benthonic, and it can constitute a source of food for other fish (BOSCOLO, 1970; FROGLIA \& OREL, 1979).

Despite its small size, $A$. boyeri is a target species of fishing and in Italy represents a commercially valuable resource of estuarine systems (MACI \& BASSETT, 2010).

Knowledge of the biological characteristics of the fish species are needed to assess the potential of its fishery and management in these habitat (MAGNIFICO, 2007). For this reason, the aim of this study was to provide basic information about some biological parameters of sand smelt, including age and growth, in the Lesina lagoon, an eastern Mediterranean coastal basin.

\section{MATERIALS AND METHODS}

\section{Study area, sampling environmental variables}

The Lesina Lagoon is situated on the Adriatic coast of Southern Italy $\left(15^{\circ} 45^{\prime} \mathrm{E}, 41^{\circ} 88^{\prime}\right.$ N) (Fig.1). Its area amounts to 5136 ha, with an

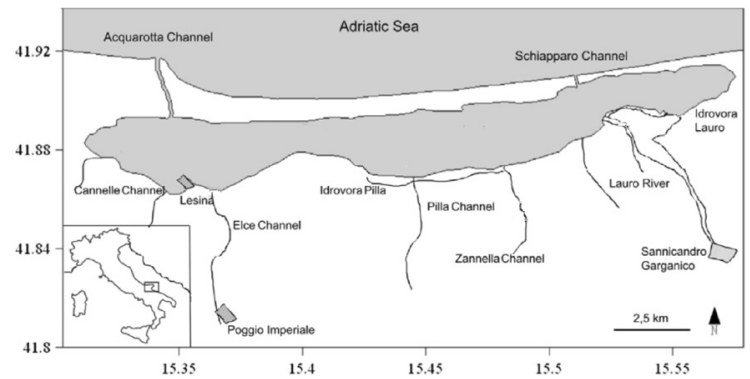

Fig. 1. The study area: Lesina Lagoon(Adriatic Sea, southern Italy)

average depth of $0.7 \mathrm{~m}$ and a maximum depth of $1.5 \mathrm{~m}$. The lagoon is connected to the sea by two tidal channels (Fig. 1). Specimens of $A$. boyeri were collected monthly by means a manual beach seine $(11 \mathrm{~m}$ long and $1.30 \mathrm{~m}$ high, the central section having a $2 \mathrm{~mm}$ mesh and the two lateral sections a $4 \mathrm{~mm}$ mesh), from June 2013 to May 2014. The capture happened maintaining a fixed side of the net and sweeping in a circular motion, at 2 knots for $15 \mathrm{~min}$, covering an area of about $150 \mathrm{~m}^{2}$.

At all sampling times a set of abiotic variables (temperature, salinity and dissolved oxygen) were directly measured by means of an Idromar IM52 multiparametric probe.

\section{Abundance, Age and Growth Parameters}

The fish sampled were measured to the nearest $0.1 \mathrm{~mm}$ from the anterior tip of the longest jaw to the most posterior part of the caudal fin (TL), and total weight (TW) was taken by an electronic balance of $0.01 \mathrm{~g}$ accuracy. Age determination based on otoliths readings and validated by length frequency analysis. Five size classes were performed (classes $0=15-29 \mathrm{~mm}$; classes $1=30-45 \mathrm{~mm}$; classes $2=46-60$; classes $3=61-80 \mathrm{~mm}$; classes $4=81-110 \mathrm{~mm}$ ).

Length-weight relationship was calculated using $\mathrm{W}=\mathrm{aTL}^{\mathrm{b}}$ equation (RICKER, 1975), where, $\mathrm{W}$ is total weight $(\mathrm{g})$, TL is total length $(\mathrm{mm})$, a is the intercept of the regression line and $b$ is the slope of the equation (exponent "b"). The variation in $\mathrm{b}$ values from 3 were tested by the t-test for evaluating growth curve. When the $b$ value in length-weight relationship was equal to or did not show statistically significant deviation from 
3 , the growth of fish was isometric, whereas when the $b$ value differed significantly from 3 the growth was allometric positive or negative (RICKER, 1975).

Relative condition factor also called Fulton's Condition factor $(\mathrm{K})$ was determined by using equation, $\mathrm{K}=\left(\mathrm{W} / \mathrm{L}^{\mathrm{b}}\right) \times 100$ as described by LE CRENS (1951) and FULTON (1911); where K is condition factor, $\mathrm{Wt}$ is total body mass $(\mathrm{g}), \mathrm{L}$ is body length $(\mathrm{mm})$ and $b$ is the allometry coefficient related to the form of the individual growth, calculated from the length-weight relationship.

The Von Bertalanffy growth function (VBGF) was used by the electronic length-frequency analysis (ELEFAN I) of the FiSAT II program package (GAYANILO et al., 2005) in order to estimate growth parameters: $\mathrm{Lt}=\mathrm{L} \infty \quad(1 \mathrm{e}-[\mathrm{k}$ $(\mathrm{t}-\mathrm{t} 0)])$, where: $\mathrm{Lt}=$ mean length at age $\mathrm{t}, \mathrm{L} \infty=$ asymptotic length $(\mathrm{mm}), \mathrm{k}=$ growth coefficient (year -1$), \mathrm{t} 0=$ theoretical age at which the length is zero.

The total mortality $(\mathrm{Z})$ was computed by a linearized length-converted catch curve (PAULY, 1984), based on the following formula:

In $(N t / \Delta t)=a+b t$, where $N$ is the number of individuals of relative age $(\mathrm{t})$ and $\Delta \mathrm{t}$ is the time needed for the fish to grow through a length class. The absolute value of the curve's slope (b) gives $\mathrm{Z}$.

Natural mortality (M) was estimated using the empirical relationship of PAULY (1980):

$\log _{10} M=-0.0066-0.279 \log _{10}(\mathrm{~L} \infty)+0.6543$ $\log _{10}(\mathrm{~K})+0.4634 \log _{10}(\mathrm{~T})$

where $\mathrm{M}$ is the natural mortality, $\mathrm{L} \infty$ the asymptotic length, $\mathrm{K}$ the growth coefficient of the VBGF and $T$ the mean annual habitat water temperature $\left({ }^{\circ} \mathrm{C}\right)$.

The computed value of $\mathrm{M}$ and $\mathrm{Z}$ Fishing were used to determine the fishing mortality $(F)$ calculated as: $\mathrm{F}=\mathrm{Z}-\mathrm{M}$. The exploitation rate $(\mathrm{E})$ was obtained from $E=F /(F+M)$ (RICKER, 1975).

The probability of capture of each size class was obtained from length-converted catch curve, by backward extrapolation of the catch curve and comparison of the numbers actually sampled with those that were expected to have been sampled. By plotting the cumulative probability of capture against the class interval, it was obtained a logistic curve from which the size at first capture (LC50\%) was taken.

The relative yield-per-recruit (Y/R) and relative biomass-per-recruit $(\mathrm{B} / \mathrm{R})$ were determined using the Beverton and Holt model modified by PAULY \& SORIANO (1986) to predict the exploitation rate at which the $Y^{\prime} / R$ is highest (Emax). In FiSAT, the recruitment patterns were analysed using the maximum likelihood approach of NORSMSEP (Separation of the Normally distributed components of length-frequency samples) to fit the Gaussian distribution on lengthfrequency data for the year pooled together (PAULY, 1983; MOREAU \& CUENDE, 1991; GAYANILO et al.,1995).

\section{Statistical Analysis}

One-way ANOVA was applied to assess the differences between growth parameters determined during the period study; when significant differences were found; the mean values were subjected to post- hoc analysis Tukey's test ( $\mathrm{p}<$ 0.05 ). Relationships between number of individuals and weight of $A$. boyeri and environmental variables (water temperature, dissolved oxygen and salinity) were determined using Pearson's correlation.

\section{RESULTS}

\section{Environmental variables}

The average values of temperature, salinity and dissolved oxygen with the relative standard deviations are shown in Fig. 2. The lagoon exhibited strong seasonal variations of abiotic parameters (ANOVA; $\mathrm{p}<0.05$ ). The water temperature followed a seasonal trend, with a minimum value in winter (January and February with values of $9-10^{\circ} \mathrm{C}$, respectively) and maximum in summer (June and July with values of 26-27 ${ }^{\circ} \mathrm{C}$, respectively). Mean monthly values of salinity ranged from $10.5 \%$ in February to $27 \%$ in September. Dissolved oxygen attained the maximum value in January $(89.6 \mathrm{mg} / \mathrm{L})$ and the minimum value in July $(50.1 \mathrm{mg} / \mathrm{L})$, and showed an inverse relationship with temperature 


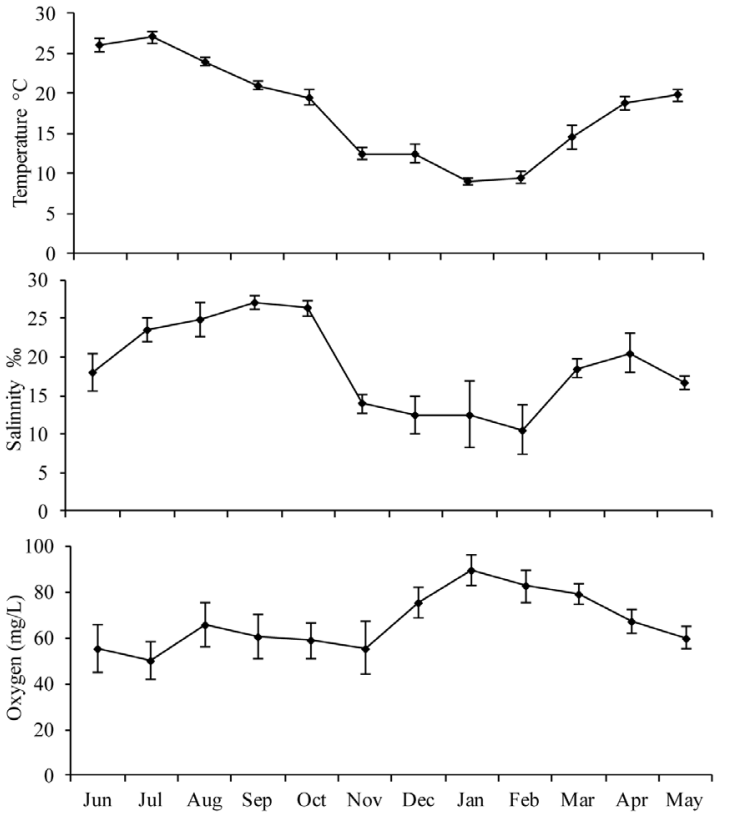

Fig. 2. Temporal variation of water temperature $\left({ }^{\circ} \mathrm{C}\right)$, salinity (\%o) and dissoved oxygen $(\mathrm{mg} / \mathrm{L})$, in the Lesina lagoon (mean \pm S.D.)

$(\mathrm{p}<0.05 ; \mathrm{r}=-0.74)$. Salinity was directly related to temperature $(\mathrm{p}<0.05 ; \mathrm{r}=0.71)$ and inversely related to dissolved oxygen $(\mathrm{p}<0.05 ; \mathrm{r}=-0.64)$.

\section{Abundance, age and growth parameters}

A total of 6553 individuals were collected, with a total weight of $8.145 \mathrm{~kg}$; individual number and total weight showed significant differences during the study period (Tukey's test; $\mathrm{p}<0.05$ ) (Fig. 3). The highest mean number of individuals was found in May and April (1295 and 984 individuals, respectively), while in March and November the lowest (188 and 200 individuals, respectively), while the highest weight of individuals was detected in August and May and the lowest in February and November (Fig. 3).

Relationships between number of individuals and weight of $A$. boyeri with environmental variables indicated that the fish abundance present in lagoon was not influenced by all the three variables measured (Tukey's test, $\mathrm{p}>0.05$ ), while the weight could be explained by the temperature only (Tukey's test $\mathrm{p}<0.05$ ).

Of the total individuals caught, a sub-sample of 2005 individuals were measured (Tab.1).

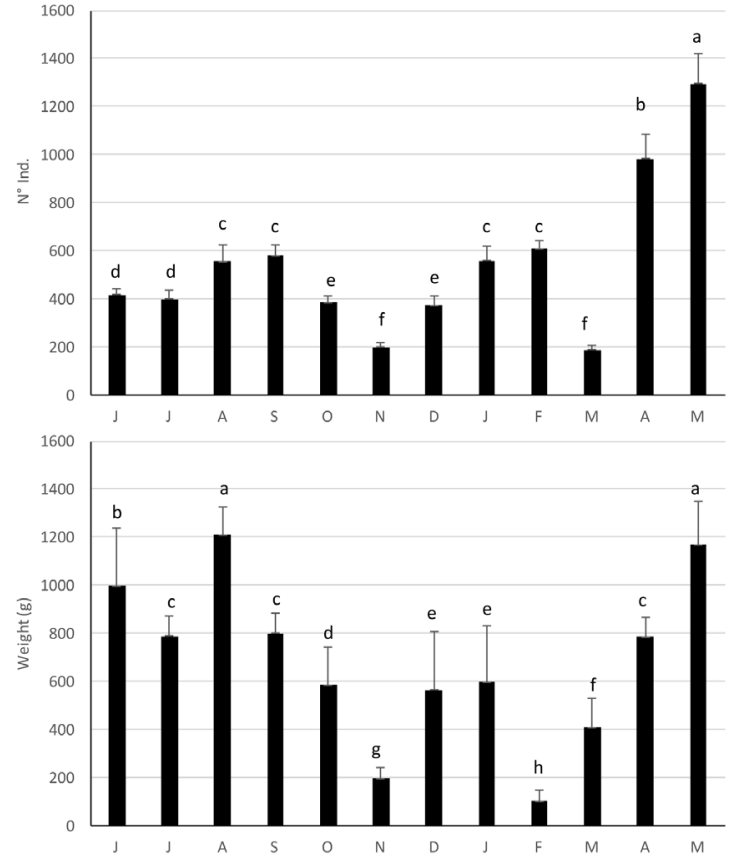

Fig. 3. Temporal distribution of Mean ( \pm s.d.) Individuals number and Mean ( \pm s.d.) Weight $(g)$ of Atherina boyeri, during experimental period. Data with different superscript letters significantly differ $(p<0.05)$

The length of specimens ranged from 15 $\mathrm{mm}$ (February) to $110 \mathrm{~mm}$ (August), while the weight ranged from $0.02 \mathrm{~g}$ (January and May) to $8.2 \mathrm{~g}$ (July) (Tab. 1).

Relationship between total length (TL) and weight for all individuals measured was described by the equation $\mathrm{W}=0.012 * \mathrm{TL} 3.10$ $\left(\mathrm{R}^{2}=0.84, \mathrm{~N}=2005\right)$ and displayed a positive allometric growth for the sand smelt population ( $\mathrm{t}$ test; $\mathrm{p}<0.05$ ). Monthly values of slope (b) ranged from a minimum of 1.51 in February to a maximum 4.59 in April, showing a significant monthly differences (Tukey's test; $\mathrm{p}<0.05$ ) (Table1).

The mean condition factor $(\mathrm{K})$ ranged from 14.4 (June) to 0.12 (April). Significant variations of the condition factor showed a decrease in growth rate during winter - spring months (except February with a value of 5.45) and an increase during summer - autumn period (Tukey's test; $\mathrm{p}<0.05$ ) (Fig. 4).

Otoliths were used for age determination of A. boyeri and five age groups $(0+-4+)$ were identified in all measured individuals. According to analysis of the otoliths, the length-con- 
Table 1. Monthly values of Atherina boyeri specimens measured: abundance (N); mean \pm standard deviation, minimum and maximum of Total Length $(\mathrm{mm})$ and Wet weight $(\mathrm{g})$; length-weight relationships parameters

\begin{tabular}{|c|c|c|c|c|c|c|c|c|c|c|c|c|}
\hline & \multirow{2}{*}{$\mathrm{N}$} & \multicolumn{4}{|c|}{ Total Length (mm) } & \multicolumn{4}{|c|}{ Wet weight(g) } & \multicolumn{3}{|c|}{$W=a T L^{b}$} \\
\hline & & Mean & S.D. & Min & $\operatorname{Max}$ & Mean & S.D. & Min & Max & $\mathrm{a}$ & $\mathrm{b}$ & $\mathrm{R}^{2}$ \\
\hline $\begin{array}{l}\text { Total individuals } \\
\text { measured }\end{array}$ & 2005 & 53.8 & 18.3 & 15.0 & 110.0 & 1.34 & 1.05 & 0.02 & 8.20 & 0.012 & 3.10 & 0.84 \\
\hline June & 164 & 75.3 & 11.7 & 38.0 & 105.0 & 2.34 & 1.09 & 0.40 & 6.37 & 0.142 & 1.82 & 0.77 \\
\hline July & 159 & 66.8 & 15.0 & 39.0 & 105.0 & 1.99 & 1.47 & 0.32 & 8.20 & 0.013 & 3.02 & 0.71 \\
\hline August & 167 & 73.3 & 14.1 & 39.0 & 110.0 & 2.44 & 01:45 & 0.29 & 7.83 & 0.065 & 2.20 & 0.67 \\
\hline September & 187 & 61.5 & 8.70 & 39.0 & 100.0 & 1.42 & 0.69 & 0.35 & 6.20 & 0.037 & 2.55 & 0.58 \\
\hline October & 139 & 6.11 & 7.80 & 42.0 & 95.0 & 1.36 & 0.63 & 0.50 & 5.50 & 0.044 & 2.45 & 0.56 \\
\hline November & 56 & 56.9 & 7.40 & 43.0 & 77.0 & 1.17 & 0.47 & 0.60 & 3.10 & 0.003 & 4.02 & 0.74 \\
\hline December & 122 & 60.2 & 10.7 & 34.0 & 98.4 & 1.40 & 0.87 & 0.38 & 6.07 & 0.001 & 3.33 & 0.63 \\
\hline January & 186 & 54.0 & 15.0 & 25.0 & 92.0 & 1.11 & 0.86 & 0.02 & 5.38 & 0.002 & 4.08 & 0.89 \\
\hline February & 220 & 19.2 & 3.50 & 15.0 & 35.0 & 0.82 & 0.77 & 0.04 & 4.24 & 0.049 & 1.51 & 0.68 \\
\hline March & 52 & 53.0 & 14.1 & 30.0 & 84.0 & 2.56 & 0.30 & 1.98 & 3.15 & 0.003 & 3.86 & 0.93 \\
\hline April & 233 & 50.1 & 8.60 & 37.0 & 80.5 & 0.72 & 0.22 & 0.36 & 1.52 & 0.001 & 4.59 & 0.80 \\
\hline May & 320 & 47.4 & 13.2 & 30.0 & 100.0 & 0.96 & 0.86 & 0.02 & 5.33 & 0.001 & 4.43 & 0.76 \\
\hline
\end{tabular}

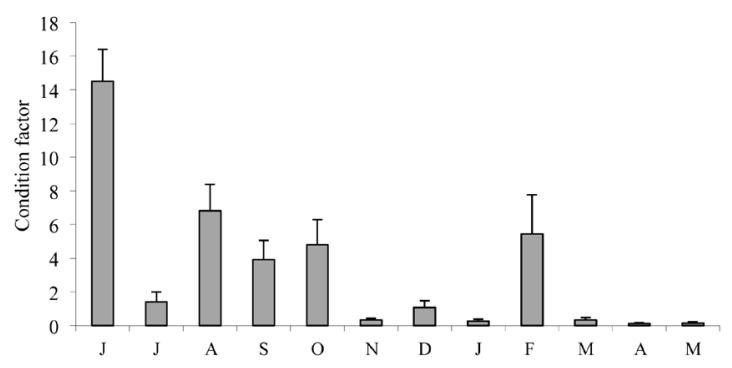

Fig. 4. Monthly Condition factor $(K)$ variation (mean \pm S.D.) of Atherina boyeri in the Lesina lagoon

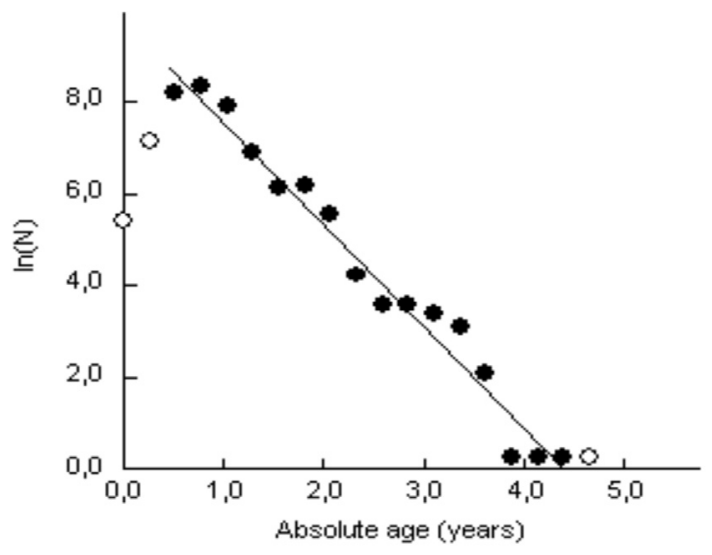

Fig. 5. Lenght-converted catch curve of the overall Atherina boyeri population in the Lesina lagoon verted catch curve for overall $A$. boyeri population (males and females) showed a longevity of about $4+$ (Fig. 5).

The population structure of $A$. boyeri was graphically represented by histograms based on length- frequency distribution. Recruitment of juvenile fish to the sampled population occurred in January until March with a peak of abundance in February (Fig. 6).
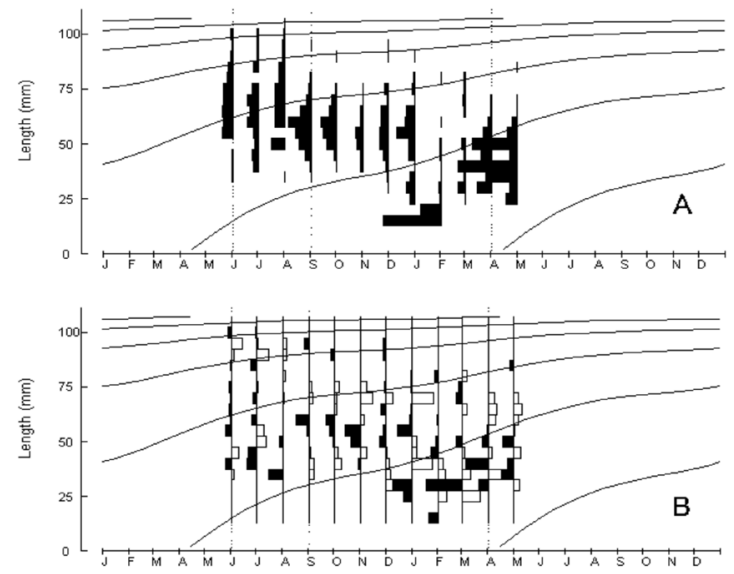

Fig. 6. Overall growth curve of Atherina boyeri population superimposed on: A) the normal total length-frequency histograms; B) the restructured; length-frequency histograms 
The von Bertalanffy growth parameters were estimated as $\mathrm{L} \infty=111.0 \mathrm{~mm}, \mathrm{~K}=0.68$ year $^{-1}$ and to $=-0.05$ year $^{-1}$ with a growth performance index $\varphi^{\prime}=3.92$ (Fig. 7).

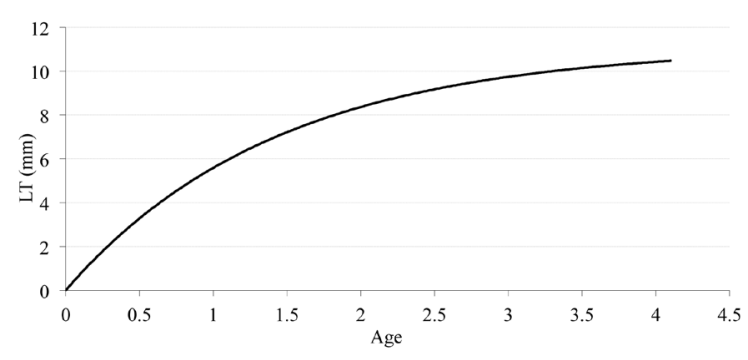

Fig. 7. Estimated von Bertalanffy growth curve during study period

\section{Mortality and exploitation}

The total mortality coefficient " $Z$ ", the natural mortality coefficient " $\mathrm{M}$ " and the fishing mortality coefficient " $F$ " were estimated as 2.24 , 1.48 and 0.76 year $^{-1}$, respectively. The estimated optimum exploitation rates (relative yield-perrecruit $(Y / R)$ and related coefficient rates (relative biomass-per-recruit $(\mathrm{B} / \mathrm{R})$ analysis were reported in Fig. 8. The maximum allowable limit of exploitation level $\left(\mathrm{E}_{\max }\right)$ that gives the maximum relative $Y^{\prime} / R$ was 0.59 , whereas the exploitation level $\left(\mathrm{E}_{0.5}\right)$ which corresponds to $50 \%$ of the relative $\mathrm{B}^{\prime} / \mathrm{R}$ of an unexploited stock was 0.34 . The probability of capture as output from FiSAT II were estimated as $\mathrm{L}_{50}=55.6 \mathrm{~mm}$.

\section{DISCUSSION}

The lagoon environment plays an important role in supporting the growth and survival of estuarine species that colonize permanently this transitional ecosystem. Lesina lagoon is a very shallow basin and for this reason its hydrological conditions are strongly influenced by environmental variables, such as seasonal temperature, precipitations trend and by discontinuity in freshwater inputs (ROSELLI et al., 2009). In addition, the tidal regime and the size of the channels limit communication with the open sea. During summer months, the increase of temperature, a low river inflow and low rainfall determine an increase of salinity. Furthermore, the high temperature favours the microbial decomposition of macroalgal biomass. Indeed, dissolved oxygen reached its lowest values during the summer and autumn months (ROSELLI et al., 2009). Notwithstanding the fluctuations of abiotic factors in the Lesina lagoon, the weight of sand smelt stock was influenced by the temperature only, while the individual number was not influenced by any of the three variables measured. The increase of $A$. boyeri's weight in summer was probably due to the trophic condition of the lagoon, to inadequate sea-lagoon water exchanges (scarce flow throughout the tidal channels) that brings an accumulation of nutrients from farmland and wastewater discharges from livestock and domestic sources. Consequently, in summer the Lesina lagoon exhibit an increase of both phytoplankton and macrophytobenthos biomass that constitute a source of food for pelagic-benthic organisms (ROSELLI et al., 2009). A. boyeri is usually reported as an opportunist or zooplanktonic feeder in marine environment (TRABELSI et al., 1994), but in shallow brackish waters can shift towards a detritus-based food web, including in its diet a wide array of small-sized benthic macroinvertebrates species (CHRISAFI et al., 2007), as confirmed by recent results based on analyses of stable isotope ratios of carbon and nitrogen (VIZZINI \& MAZZOLA, 2002, 2005).

The high degree of sand smelt plasticity allows adaptation of life history responses to environmental variables characteristic of coastal and lagoonal habitats; the sand smelt is thus pre-adapted for the exploitation of novel and vacant niches (HENDERSON \& BAMBER, 1987). $A$. boyeri in the Lesina lagoon showed a temporal variability in size structure and body condition as observed in other ecosystems. HENDERSON \& BAMBER (1987) indicated that the growth and maximum size could reduce along an oceaniccoastal-estuarine-freshwater habitat range.

It has been shown that sand smelt population vary greatly in longevity and maximum size attained. The maximum values of the total length and weight observed in the population of the Lesina lagoon were $110 \mathrm{~mm}$ and $8.2 \mathrm{~g}$ respectively. Similar results were reported by LEONARDOS (2001) for the same species. 
The lifespan of the $A$. boyeri is short and five age groups $(0+-4+)$, were observed. Similar age groups were reported for specimens from the English Channel (HENDERSON \& BAMBER, 1987), Trichonis lake, Western Greece (LEONARDOS, 2001), Pantana lagoon, Croatia (PALLAORO et al., 2002), Vistonis lake and Porto Lagos lagoon, Northen Greece (KOUTRAKIS et al., 2004) Vaccares lagoon, Southern France (ROSECCHI \& CRIVELLI, 1995). However, several authors reported a shorter life cycle (GON \& BEN-TUVIA, 1983; LEONARDOS \& SINIS, 2000; LEONARDOS, 2001; BARTULOVIĆ et al., 2004; POMBO et al., 2005; PATIMAR et al., 2009; ANDREU-SOLER et al., 2003).

HENDERSON and BAMBER (1987) indicated that sand smelt can adapt its life span, morphology and growth to environmental and geographical locations.

For applied ichthyological studies, 'b' of length-weight relationship is an important key parameter in estimating population growth. Significant monthly variations in slope were observed, in winter and spring, with the slope higher in correspondence of higher concentrations of dissolved oxygen, suggesting that individuals have more metabolic requirements (PETERS, 1986; CLARKE \& JOHNSTON, 1999). The values of slope were similar in other European regions that reported a positive allometric growth (PALMER \& CULLEY, 1983; CREECH, 1992; LEONARDOS \& SINIS, 2000; LEONARDOS, 2001; ANDREU-SOLER et al., 2003; BARTULOVIĆ et al., 2004; KOUTRAKIS et al., 2004; MACI \& BASSET, 2010).

In the present study, individuals were not sexed and gonads were not analysed. HENDERSON et al. (1988) reported that the post-larvae of $A$. boyeri developed rapidly reaching the length of $24 \mathrm{~mm}$ within 2 months. In the Lesina basin small sized individuals were collected in January, February (in high number) and in the catches of May. This probably suggests the occurrence of a spawning season extending from November to April/May. In the summer and early autumn months length-frequency distribution was characterized by individuals ranging from 36 to $110 \mathrm{~mm}$. During these months the individuals body condition increased, probably due to an increased food availability, that favour larger individuals having a greater ability to feed and increase body mass and fat content. This distribution change in November, when the larger classes disappear and the body condition drop.

In general, the observations regarding the sand smelt condition factor in Lesina lagoon was similar to that reported in other populations (MARFIN 1982, FERNÁNDEZ - DELGADO et al., 1988, ANDREU-SOLER et al., 2003; KOUTRAKIS et al., 2004). The rapid early growth rate through age one was typical of most Atherinids (BOSCOLO, 1970; PALMER \& CULLEY, 1983; HENDERSON \& BAMBER, 1987; FERNANDEZ-DELGADO et al.,1988; CREECH, 1992). Comparison of $K$ and $L \infty$ from different lagoon populations in the Mediterranean and the Atlantic coast of Europe showed growth patterns different. In this study, the estimated value of $\mathrm{L} \infty$ was similar to that Greek Mediterranean lagoons (LEONARDOS \& SINIS, 2000; LEONARDOS, 2001), whereas total mortality, natural mortality and of fishing mortality are higher than values reported by KOUTRAKIS et al. (2004) in the Northern Greece.

Also the estimated exploitation rate $(\mathrm{E}=$ 0.34 ) showed that fishing mortality was lower than natural mortality. The implication is that $A$. boyeri die more due to natural death than human exploitation, therefore, one can infer that the stock of $A$. boyeri is probably submitted to a low fishing pressure. This is based on the assumption that in an optimally exploited stock, natural and fishing mortalities should be equal or $\mathrm{E}=$ $\mathrm{F} / \mathrm{Z}=0.5$ (GULLAND, 1971). PAULY (1987) and PATTERSON (1992) reported that exploitation rates below 0.4 suggest the tendency toward stock recovery and can be used as a guideline for the sustainable exploitation of small pelagic species.

\section{CONCLUSIONS}

Atherina boyeri is important fishery resource, in the Lesina lagoon since it was caught all year round and seem well adapted in this variable environment.

The life traits of this semi-isolated lagoonal population is similar to that of Mediterranean coastal ecosystems. The actual fishery pres- 
sure is lower than the exploitation level, which maximizes the relative yield per recruit, a programmed and long term monitoring of the population dynamics and fishery is required in order to confirm the present findings and to maintain the best equilibrium of $A$. boyeri resource in the Lesina lagoon.

\section{REFERENCES}

ANDREU-SOLER, A., F. J. OLIVA-PATERNA, C. FERNÀNDEZ-DELGADO \& M. TORRALVA 2003. Age and growth of the sand smelt, Atherina boyeri (Risso 1810), in the Mar Menor coastal lagoon (SE Iberian Peninsula). J. Appl. Ichthol., 19: 202-208.

BARTUlOVIĆ, V., B. GLAMUZINA, A. CONIDES, D. DULČIĆ, J. NJIRE \& V. KOŽUL. 2004. Age, growth, mortality and sex ratio of sand smelt, Atherina boyeri Risso, 1810 (Pisces: Atherinidae) in the estuary of the Mala Neretva River (middle-eastern Adriatic, Croatia). J. Appl. Ichthol., 20: 427-430.

BASSET, A., L. SABETTA, A. FONNESU, D. MOUILLOT, T. DO CHI, P. VIAROLI, G. GIORDANI, S. REIZOPOULOU, M. ABBIATI \& G.C. CARRADA. 2006. Typology in Mediterranean transitional waters: new challenges and perspectives. Aquat. Cons. Mar. Fresh. Eco. 16, 441-455.

BOSCOLO, L. 1970. Osservazioni sulla biologia e sulla pesca dell'Atherina boyeri Risso 1810 (Osteichthyes, Atherinidae) vivente nelle acque dell'Alto Adriatico. Boll. Pesca, Pisc. Idrobiol., 25: 61-79.

CHRISAFI, E., P. KASPIRIS \& G. KATSELIS. 2007. Feeding habits of sand smelt (Atherina boyeri, Risso 1810) in Trichonis Lake (Western Greece). J. Appl. Ichthol., 23: 209-214.

CLARKE, A. \& N.M., JOHNSTON. 1999. Scaling of metabolic rate with body mass and temperature in teleost fish. J. Anim. Ecol. 68: 893-905.

CREECH, S. 1992. A study of the population biology of Atherina boyeri Risso, 1810 in Aberthaw Lagoon, on the Bristol Channel, in South Wales. J. Fish Biol. 41: 277-286.

ELLIOTT, M. \& F. DAWAILLY. 1995. The structure and components of European estuarine fish assemblages. Netherl. J. Aquatic Ecol. 29: 397-417.

FERNANDEZ-DELGADO, C., J.A. HERNANDO, M. HERRERA \& M. BELLIDO. 1988. Life history patterns of the sand smelt Atherina boyeri Risso, 1810 in the estuary of the Guadalquivir River, Spain. Estuar. Coast. Shelf Sci., 27: 697-706.

FRANCO, A., P. FRANZOI, S. MALAVASI, F. RICCATO, P. TORRICELLI \& D. MAINARDI. 2006. Use of shallow water habitats by fish assemblages in a Mediterranean coastal lagoon. Estuar. Coast. Shelf Sci., 66: 67-83.

FROGLIA, C. \& G. OREL. 1979. Considerazioni sulla pesca a strascico nella fascia costiera delle tre miglia in Adriatico. Atti Soc. Toscana Sci Nat., 86: 17-25.

FULTON, T. W. 1911. The sovereignty of the sea. London. Edinburgh. pp. 799

GAYANILO, F.C. Jr., P. SPARRE \& D. PAULY. 1995. The FAO--ICLARM Stock Assessment Tools (FiSAT). user's guide. FAO Computerized Information Series (Fisheries). Rome: FAO 7: 126 p.

GAYANILO, F.C. Jr., P. SPARRE \& D. PAULY. 2005. FaoIclarm Stock Assessment Tools II (FiSAT II). Revised version. User's Guide. FAO Computerized Information Series (Fisheries). $N^{\circ} 8$, Revised version. Rome: FAO 168 p.

GON, O. \& A. BEN-TUVIA. 1983. The biology of Boyer's sand smelt, Atherina boyeri Risso, 1810 in the Bardawil Lagoon on the Mediterranean coast of Sinai. J. Fish Biol., 22: 537-547.

GORDO, L.S. \& CABRAL, H.N. 2001. The fish assemblage structure of a hydrologically altered coastal la- goon: the Óbidos lagoon (Portugal). Hydrobiologia, 459: 125-133.

GULLAND, J.A. 1971. The fish resources of the ocean. Fishing News (Books) Ltd, West Byfleet, UK. 225p.

HENDERSON, P.A. \& R.N. BAMBER. 1987. On the reproductive biology of the sand smelt Atherina boyeri Risso (Pisces: Atherinidae) and its evolutionary potential. Biol. J. Linn. Soc., 32: 395-415.

HENDERSON, P.A., R.H.A. HOLMES \& R.N. BAMBER. 1988. Size-selective overwintering mortality 
in the sand smelt, Atherina boyeri Risso, and its role in population regulation. J. Fish Biol., 33: 221-233.

KOUTRAKIS, E.T., N.I. KAMIDIS \& I.D. LEONARDOS. 2004. Age, growth and mortality of a semi-isolated lagoon population of sand smelt, Atherina boyeri (Risso, 1810) (Pisces: Atherinidae) in an estuarine system of northern Greece. J. Appl. Ichthol., 20: 382-388.

LE CREN, E.D. 1951. The length-weight relationship \& seasonal cycle in gonad weight $\&$ condition in perch (Perca fluviatilis). J. Anim. Ecol. 20. 201-219.

LEONARDOS, I.D. \& A. SINIS. 2000. Age, growth and mortality of Atherina boyeri Risso, 1810 (Pisces: Atherinidae) in the Mesolongi and Etolikon lagoons (W. Greece). Fish. Res., 45: 81-91.

LEONARDOS, I.D. 2001. Ecology and exploitation pattern of a landlocked population of sand smelt, Atherina boyeri (Risso, 1810), in Trichonis Lake (western Greece). J. Appl. Ichthol., 17: 262-266.

MACI, S. \& A. BASSET. 2010. Spatio-temporal patterns of abundance, size structure and body condition of Atherina boyeri (Pisces: Atherinidae) in a small non-tidal Mediterranean lagoon. Estuar. Coast. Shelf Sci., 87: 125-134.

MAGNIFICO, G. 2007. New Insights into fish growth parameters estımation by Means of length-based methods. Ph.D. Thesis in Evolutionary Biology and Ecology XIX cycle Tor Vergata University of Rome, 202 pp.

MARFIN, J.P. 1982. Croissance de l'Atherine Atherina boyeri Risso, 1810 dans trois milieux saumatres du Roussillion. Bull. . Inst. Nat. Sci. Tech. Ocean. Peche Salammbo, 9: 89-109.

MCLUSKY, D.S. \& M. ELLIOTT. 2004. The Estuarine Ecosystem: Ecology, Threats and Management. $3^{\text {th }}$ edition, Oxford University Press, Oxford. p. 224.

MOREAU, J. \& F.X. CUENDE. 1991. On improving of resolution of the recruitment pattern of fishes ICLARM. Fishbyte, 9: 45-46.

PALLAORO, A., M. FRANIEEVIE \& S. MATIE. 2002. Age, growth and mortality of big-scale sand smelt, Atherina (Hepsetia) boyeri Risso 1810 in the Pantana Lagoon. Croat. Per. Biol., 104: 175-183.

PALMER, C.J. \& M.B. CULLEY. 1983. Aspects of the biology of the sand smelt Atherina boyeri Risso, 1810 (Teleostei: Atherinidae) at Oldbury-upon-Severn, Gloucestershire, England). Estuar. Coast. Shelf Sci., 16: 163-172.

PATIMAR, R., M. YOUSEFI, \& S.M. HOSIENI. 2009. Age, growth and reproduction of the sand smelt Atherina boyeri Risso, 1810 in the Gomishan wetland - southeast Caspian Sea. Estuar. Coast. Shelf Sci., 81: 457-462.

PATTERSON, K. 1992. Fisheries for small pelagic species: an empirical approach to management targets. Rev. Fish Biol. Fish., 2: 321338 .

PAULY, D. 1980. On the interrelationships between natural mortality, growth parameters and mean environmental temperature in 175 fish stocks. ICES J. Mar. Sci., 39: 175-192.

PAULY, D. 1983. Some simple methods for the assessment of tropical fish stock. FAO Fisheries Technical Paper, 234: 1-52.

PAULY, D. 1984. Fish population dynamics in tropical waters: a manual for use with programmable calculators. ICLARM Studies and Reviews 8325, p. 325.

PAULY, D. 1987. A review of the ELEFAN system for analysis of length frequency data in fish and aquatic invertebrates. In: D. Pauly \& G.R. Morgan, (Editors). Length-based methods in fisheries research. ICLARM, Manila, pp. 7-34.

PAULY, D. \& M.L. SORIANO. 1986. Some practical extensions to Beverton and Holt's relative yield-per-recruit model. In: J.L. Maclean, B. and L. Dizon \& L.V. Hosillo, (Editors). The First Asian Fisheries Forum. Manila: Asian Fisheries Society, pp. 491-496.

PETERS, R.H. 1986. The Ecological Implications of Body Size. Cambridge University Press, Cambridge, UK p. 329.

POMBO, L., M. ELLIOTT \& J.E. REBELO. 2005. Ecology, age and growth of Atherina boyeri and Atherina presbiter in the Ria de Aveiro, Portugal. Cybium, 29(1): 47-55.

QUIGNARD, J.P. \& A. PRAS. 1986. Atherinidae. In: P. Whitehead, M.L. Bauchot, J.C. Hureau, J. Nielsen \& E. Tortonese (Editors). Fishes 
of the North-eastern Atlantic and Mediterranean, UNESCO, Paris, pp.1207-1210.

RICKER, W.E. 1975. Computation and interpretation of biological statistics of fish populations. Bulletin of the Fisheries Research Board of Canada, 191: 1-382.

ROSECCHI, E. \& A.J. CRIVELLI. 1995. Sand smelt (Atherina boyeri) migration within the water system of the Camargue, southern France. Hydrobiologia, 300/301: 289-298.

ROSELlI, L., A. FABBROCINI, C. MANZO \& R. D'ADAMO. 2009. Hydrological heterogeneity, nutrient dynamics and water quality of a nontidal lentic ecosystem (Lesina Lagoon, Italy). Estuar. Coast. Shelf Sci., 84: 539-552.

TRABELSI, M., J.P. QUIGNARD \& F. KARTAS. 1994.
Atherina boyeri: Premiere mention en Mediterranee de deux populations marines sympartiques. Cybium, $18:$ 457-459.

VIZZINI, S. \& A. MAZZOLA. 2002. Stable carbon and nitrogen ratios in the sand smelt from a Mediterranean coastal area: feeding habits and effect of season and size. J. Fish Biol., 60: 1498-1510.

VIZZINI, S. \& A. MAZZOLA. 2005. Feeding ecology of the sand smelt Atherina boyeri (Risso 1810) (Osteichthyes, Atherinidae) in the western Mediterranean: evidence for spatial variability based on stable carbon and nitrogen isotopes. Env. Biol. Fish., 72: 259-266.

Received: 28 May 2019

Accepted: 4 June 2020 


\title{
Rast, smrtnost i prinos olige (Atherina boyeri Risso, 1810) iz lagune Lesina (Jadransko more, Italija)
}

\author{
Ermelinda PRATO ${ }^{*}$, Asia GRATTAGLIANO², Daniela LUMARE ${ }^{3}$, Febo LUMARE ${ }^{3}$, \\ Andrea RUSCITO i Francesca BIANDOLINO ${ }^{1}$ \\ *Kontakt adresa, e-pošta: linda.prato@irsa.cnr.it
}

\begin{abstract}
SAŽETAK
Istraživana je struktura populacije, rast, starost, smrtnost i status eksploatacije olige Atherina boyeri, ulovljene u razdoblju od lipnja 2013. do svibnja 2014. u laguni Lesina (regija Apulija, južni Jadran). Uzorci su uzimani svaki mjesec pomoću mreže potegače.

Dužinsko-maseni odnos opisan je jednadžbom $\mathrm{W}=0,012 * \mathrm{TL} 3,10$; $(\mathrm{R} 2=0,84)$. Utvrđeni su parametri populacije, uključujući asimptotsku duljinu $(\mathrm{L} \infty)$ i koeficijent rasta $(\mathrm{K})$, kako bi se procijenilo stanje zaliha.

Obrazac novačenja modeliran je FiSAT rutinom. Asimptotska duljina (L $\infty)$ iznosila je 111,0 mm, dok je koeficijent rasta $(\mathrm{K})$ iznosio 0,68 godina $^{-1}$. Indeks učinka rasta $(\varphi$ ') dosegnuo je 3,92. Ukupni koeficijent smrtnosti „Z“, koeficijent prirodne smrtnosti „, $\mathrm{M}^{\prime}$ i koeficijent mortaliteta ribolova „F“ procijenjeni su na 2,24, 1,48 i 0,76 godina $^{-1}$.

Stopa eksploatacije populacije olige u Lesinskoj laguni procijenjena na 0,34 rezultirala je i dalje nižom od predviđene maksimalne vrijednosti Emax 0,59.
\end{abstract}

Ključne riječi: Atherina boyeri, mjesečne varijacije, starost, rast, smrtnost, eksploatacija, laguna Lesina, Jadransko more 
